\title{
Дослідження процесу деформування матеріалу поршневих пальців при їх відновленні
}

\author{
А.А. Дудніков ${ }^{1}$, В.В. Дудник ${ }^{2}$, О.І. Біловод ${ }^{3}$, О.В. Іванкова ${ }^{4}$, Т.Г. Лапенко ${ }^{5}$ \\ Полтавська державна аграрна академія (м. Полтава, Україна) \\ email:1 anat_dudnikov@ukr.net, ORCID:10000-0001-8580-657X, 2 0000-0002-6553-2951, \\ ${ }^{3}$ 0000-0003-3470-0091, 4 0000-0003-1825-0262, 5 0000-0001-8055-6698
}

Розглянуті методи, які забезпечують підвищення довговічності двигунів сільськогосподарської техніки за рахунок використання ефективних технологій при виготовленні та відновленні поршневих пальців. Запропонований метод відновлення поршневих пальців автотракторних двигунів 3 використанням механічних вібраційних коливань обробляючого інструменту.

Проведені дослідження по вибору основних параметрів обробляючого інструмента - пуансона, які сприяють підвищенню якості відновлення поршневих пальців двигунів, що забезпечує їх підвищену зносостійкість і, відповідно, надійність двигуна.

Встановлені види головних деформацій при обробці матеріалу пальців по їх довжині, зовнішньому і внутрішньому діаметрах із вказанням їх особливостей. Досліджені зміни розмірів оброблюваних зразків по їх довжині в умовах звичайного і вібраційного навантаження.

Знайдені значення ступеню зміцнення матеріалу поршневих пальців і бронзових втулок.

Проведені мікроструктурні дослідження з метою визначення впливу методу десормування на властивості металу поршневих пальців. Досліджений вплив методу обробки поршневих пальців на процес переносу (налипання) їх матеріалу на робочу поверхню обробляючого інструменту пуансону. Проведені дослідження зносостійкості зразків, вирізаних з поршневих пальців і бронзових втулок двигунів на машині тертя за схемою «ролик - колодочка».

Визначена інтенсивність зносу вказаної пари тертя по середній величині втрати маси ролика і колодочки. Приведені графрічні залежності результатів зношування ролика і колодочки при звичайному і вібраційному деформуванні в залежності від часу випробувань.

Результати стендових досліджень дозволяють розробити і впровадити у виробництво технологічний процес відновлення поршневих пальців і бронзових втулок методом вібраційного деформування.

Ключові слова: довговічність деталей; обробляючий інструмент; вібраційне зміцнення; зносостійкість; технологічний процес.

Застосування ефрективних технологій при виготовленні і відновленні зношених деталей двигунів забезпечує високу їх зносостійкість. До таких методів відноситься метод вібраційного деформування матеріалу деталей.

В зв'язку з цим актуальним $є$ питання дослідження процесу відновлення конкретних деталей вібраційним пластичним деформуванням. Тому матеріал даної роботи є актуальним, так як включає розробку і застосування розробленої технології підвищення довговічності роботи комбайнових двигунів шляхом зміцнюючих обробок поршневих пальців.

Методи підвищення довговічності деталей машин можуть бути трьох видів: конструктивні, технологічні та експлуатаційні.

Конструкційні методи включають: вибір матеріалу деталей; забезпечення їх рівноміцності.

До технологічних методів відносяться заходи поліпшення властивостей матеріалів, що застосовуються: обкатування робочих поверхонь деталей; обробка стальних деталей СВЧ; нанесення на робочі поверхні деталей металевих матеріалів з високими експлуатаційними властивостями.

Вказані способи не знайшли ще широкого застосування, що пояснюється наступними причинами: досить широкий діапазон зносу вказаних деталей; різні фрізико-механічні властивості матеріалів та умови експлуатації.

Метод обробки деталей на основі використання вібрацій пов'язаний з поняттям збурюючої сили, яка може мінятися по величині і по напряму.

Впровадження вібраційних методів підвищує рівень автоматизації багатьох трудомістких процесів, збільшує економічну ефективність праці. Основою вібраційного зміцнення $є$ динамічний характер протікання процесу, що супроводжується безліччю мікроударів робочого інструменту по поверхні оброблюваних деталей. Це забезпечує пластичну дефрормацію поверхневого шару i підвищення мікротвердості. 
Зносостійкість обробленого матеріалу деталей вібраційною деформацією визначається значною мірою глибиною зміцненого шару. У літературі відсутні конкретні рекомендації по визначенню її величини.

У літературі наводяться деколи суперечливі дані про вплив вібраційної обробки на структуру поверхневого шару оброблених деталей.

Як вважають автори [2], питання вібраційної деформації деталей типу втулок ще не отримало достатнього освітлення.

Тому проведення подальших досліджень по вібраційній дефрормації деталей з метою розробки технології їх відновлення представляє як теоретичний, так і практичний інтерес.

Для визначення технології відновлення зношених деталей необхідно вибрати параметри обробки, які залежать від величини їх зносу.

Вимірювання поршневих пальців по зовнішній поверхні проводили індикаторною скобою 3 точністю відліку 0,001 мм.

Експериментальні дослідження деформації зразків-втулок та відновлення зношених деталей методом вібраційного деформування проводились на вібраційній установці.

Спочатку експериментальні дослідження проводились в лабораторних умовах на зразках, а потім отримані дані перераховували на конкретні деталі (поршневі пальці) з метою визначення зусилля обробки, впливу умов деформації на зміни структури та властивостей металу, що забезпечує його зміцнення.

Коливання робочого інструменту (пуансону) сприяють змінам фізико-механічних властивостей металу, що обробляється.

Зносостійкість оцінювали по середній для випробуваних зразків інтенсивності зношування.

При обробці матеріалу деталей тиском відбуваються деформації, в результаті чого змінюються їх розміри.

При роздачі пустотілого зразка циліндричної форми деформаційний стан характеризується трьома головними деформаціями: двома рівними між собою деформаціями розтягнення $\varepsilon_{1}$ і $\varepsilon_{2}$ в радіальному напрямку і деформацією стиснення $\varepsilon_{3}$ в напрямку дії обробляючої сили.

Сумарна відносна деформація по довжині зразка з початковою довжиною $l_{0}$ i кінцевою $l_{1}$ складає:

$$
\delta l=\int_{l_{0}}^{l_{1}} \frac{d l}{l}=\ln \frac{l_{1}}{l_{0}} .
$$

По зовнішньому діаметру $D$ і внутрішньому $d$ сумарну відносну деформацію можна записати:

$$
\delta_{D}=\int_{D_{0}}^{D_{1}} \frac{d D}{D}=\ln \frac{D_{1}}{D_{0}}
$$

$$
\delta_{d}=\int_{d_{0}}^{d_{1}} \frac{d d}{d_{0}}=\ln \frac{d_{1}}{d_{0}}
$$

Стосовно роздачі пустотілого зразка (поршневого пальця) величина $\delta /$ від'ємна, $\delta_{D}$ і $\delta_{d}-$ додатні.

При розробці технологічного процесу відновлення для деталей типу втулок необхідно знати зусилля деформування для подолання опору металу десрормації і тертя на контактній поверхні зразка з інструментом.

В літературі $€$ деякі рекомендації теоретичного розрахунку зусилля деформування [3]:

$$
P=F_{n} \cdot \sigma_{m}\left(1-0,5 \frac{2 \mathrm{fl}}{\delta_{\mathrm{BT}}}\right),
$$

де $F_{n}$ - площа поперечного перерізу втулки; $f$ - коефіцієнт тертя; $I$ - довжина втулки; $\delta_{\text {вт }}-$ товщина стінки втулки; $\sigma_{T}-$ опір дефрормації.

В якості робочого інструменту використовували пуансон конусної форми з наступними значеннями кутів ухилу: $10^{\circ} ; 11^{\circ} ; 12^{\circ}$.

В процесі деформування зразків відбувається налипання металу оброблюваної поверхні на робочу поверхню пуансона, що негативно впливає на якість обробки: знижує якість обробленої поверхні; збільшує нерівномірність деформації в радіальному напрямку і по довжині зразка. Крім того зростає зусилля обробки.

В таблиці 1 приведені значення величин налипання металу на поверхню пуансона залежно від кута ухилу, матеріалу оброблюваних деталей і способу деформації.

Таблиця 1. Величина налипання металу

\begin{tabular}{|c|c|c|c|c|c|c|}
\hline \multirow{7}{*}{$\begin{array}{c}\text { При- } \\
\text { пуск } П, \\
\text { мм }\end{array}$} & \multicolumn{7}{|c|}{$\begin{array}{c}\text { Сталь } 45 \\
\text { загартована }\end{array}$} & \multicolumn{3}{c|}{ Сталь 45} \\
\cline { 2 - 6 } & $\beta=10^{\circ}$ & $\beta=11^{\circ}$ & $\beta=12^{\circ}$ & $\beta=10^{\circ}$ & $\beta=11^{\circ}$ & $\beta=12^{\circ}$ \\
\hline \multicolumn{7}{|c|}{ Звичайна деформація } \\
\hline 0,3 & 0,004 & 0,003 & 0,006 & 0,005 & 0,004 & 0,007 \\
\hline 0,4 & 0,006 & 0,004 & 0,010 & 0,009 & 0,008 & 0,011 \\
\hline 0,5 & 0,010 & 0,009 & 0,015 & 0,012 & 0,010 & 0,016 \\
\hline \multicolumn{7}{|c|}{ Вібраційна дефорормація } \\
\hline 0,3 & - & - & - & - & - & - \\
\hline 0,4 & - & - & - & 0,002 & 0,001 & 0,004 \\
\hline 0,5 & 0,02 & 0,001 & 0,002 & 0,003 & 0,004 & 0,006 \\
\hline
\end{tabular}

Експериментально встановлено, що мінімальне налипання металу має місце при куті ухилу пуансона $\beta=11^{\circ}$ як в умовах звичайної, так і вібраційної деформації зразків. Таким чином, кут ухилу $\beta=11^{\circ} €$ оптимальним.

Для з'ясування ступеня впливу висоти калібруючої частини пуансона на якість оброблюваної поверхні зразків пуансони виготовлялися з висотою калібруючої частини 2, 4 і 6 мм. 
Дослідження проводили на зразках довжиною 100 мм із загартованої сталі 45 з припуском на обробку П=0,5 мм в умовах звичайної та вібраційної деформації (табл. 2)

Таблиця 2. Зміна параметра $R_{z}$ оброблюваної поверхні

\begin{tabular}{|c|c|c|}
\hline \multirow{2}{*}{$\begin{array}{c}\text { Висота } \\
\text { калібруючої } \\
\text { частини } h, \text { мм }\end{array}$} & \multicolumn{2}{|c|}{ Значення параметра $R_{z}$} \\
\hline & $\begin{array}{c}\text { Вібраційна } \\
\text { деформація }\end{array}$ & $\begin{array}{c}\text { Звичайна } \\
\text { деформація }\end{array}$ \\
\hline 2 & 6,0 & 12,5 \\
\hline 4 & 3,1 & 8,2 \\
\hline 6 & 6,4 & 25,1 \\
\hline
\end{tabular}

Лінійне значення шорсткості при звичайній і вібраційній деформації мають місце при висоті калібруючого пояска 4 мм.

Величина деформації зразків (деталей) залежить від наступних основних фракторів: частоти, припуску на обробку, розміру і матеріалу зразків, виду змащення, швидкості обробки.

Для визначення величини деформації деформуванню піддавались зразки-втулки з наружним діаметром $D=40$ мм і внутрішнім $D_{o}=22,2 \ldots 24,5 \mathrm{~mm}$

Дослідженнями встановлено, що розміри верхньої і нижньої частини втулок по діаметру відхиляються від діаметра калібруючої частини пуансона: в верхній частині в сторону збільшення, а в нижній - в сторону зменшення. При вібраційному деформуванню ці параметри мають більше значення, ніж при звичайному. Це може бути пояснено інтенсифікацією процесу ковзання дислокацій.

В процесі деформування зразків-втулок відбувається зміна їх довжини. Величина деформації зразків $I=100$ мм при припуску $П=2,5$ мм і куті ухилу пуансона $\beta=11^{\circ}$ склала при звичайному деформуванню 0,98 мм, а при вібраційному - 0,42 мм.

Ступінь деформування по довжині зразків при звичайному деформуванні в 2,33 рази більше, ніж при вібраційному.

В процесі проведених досліджень зусилля обробки визначалось за допомогою показників манометра. Результати замірів зусилля при звичайному і вібраційному деформуванню для зразків $I=110$ мм і $\vartheta=0,30$ м/с приведені в табл. 3 .

Зусилля деформування, як видно із даних таблиці, змінюється з підвищенням припуску на обробку, кута ухилу пуансона і методу обробки. Для вказаних значень припусків зусилля деформування при вібраційній обробці в 2,05...2,7 менше, ніж при звичайній.

Для оцінки якості матеріалу зразків, підданих звичайному і вібраційному деформуванню, проведені дослідження мікроструктури на шліфрах. Розмір зерен визначали методом візуальної оцінки у відповідності з ГОСТ 5639-82, що полягає у визначенні величини зерна порівнюванням видимих під мікроскопом зерен з еталонною шкалою. При вібраційному деформуванні величина зерен склала 6 балів, а при звичайному - 4 бали.

Таблиця 3. Величина зусилля деформування

\begin{tabular}{|c|c|c|c|}
\hline \multicolumn{2}{|c|}{$\begin{array}{c}\text { Звичайне } \\
\text { дефрормування }\end{array}$} & \multicolumn{2}{|c|}{$\begin{array}{c}\text { Вібраційне } \\
\text { деорормування }\end{array}$} \\
\hline \multicolumn{2}{|c|}{$\beta=11^{\circ}$} & \multicolumn{2}{|c|}{$\beta=11^{\circ}$} \\
\hline $\begin{array}{c}\text { Припуск } \\
\text { П, мм }\end{array}$ & $\begin{array}{c}\text { Зусилля } P, \\
\mathrm{MH} / \mathrm{M}^{2}\end{array}$ & $\begin{array}{c}\text { Припуск } \\
\text { П, мм }\end{array}$ & $\begin{array}{c}\text { Зусилля } P \\
\mathrm{MH} / \mathrm{M}^{2}\end{array}$ \\
\hline 0,5 & 2,65 & 0,5 & 0,98 \\
\hline 1,0 & 3,83 & 1,0 & 1,75 \\
\hline 1,5 & 4,71 & 1,5 & 2,30 \\
\hline 2,0 & 6,07 & 2,0 & 2,77 \\
\hline 2,5 & 7,33 & 2,5 & 3,05 \\
\hline
\end{tabular}

Дослідженнями встановлено, що при вібраційному деформуванні спостерігається більш рівномірна структура металу зразків по перетину (рис. 1). При цьому зерна виходять більш дрібної величини і мають деяку витягнутість в напрямку руху пуансона.
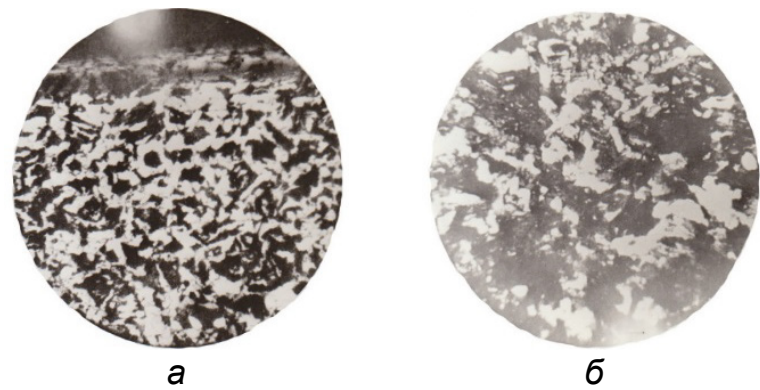

Рис. 1. Мікроструктура зразків х 300: а - вібраційне деформування; б - звичайне деформування.

По середній величині втрати маси ролика і колодочки визначали інтенсивність зносу. В табл. 4 приведені дані зносу зразків, відновлених звичайним і вібраційним деформуванням.

При вібраційному деформуванні знос ролика в 1,2, а колодочки в 1,28 рази менше, ніж при звичайному. Менша величина зносу свідчить про більш високу зносостійкість деталей, відновлених методом вібраційного деформування.

На рис. 2 представлені криві зносу пари тертя «ролик-колодочка» при $P=1700 \mathrm{H}$ і $n=500$ хв$^{-1}$.

\section{Висновки}

1. Мінімальне налипання металу на поверхню пуансона має місце при його куті ухилу $\beta=10^{\circ}$ в умовах звичайної, так і вібраційної деформації

2. Мінімальне значення шорсткості при звичайній і вібраційній деформації мають місце при висоті калібруючого пояска 5 мм. 
Таблиця 4. Результати зносу ролика і колодки

\begin{tabular}{|c|c|c|c|c|}
\hline \multirow{2}{*}{$\begin{array}{c}\text { Номер } \\
\text { пари } \\
\text { тертя }\end{array}$} & \multicolumn{2}{|c|}{$\begin{array}{c}\text { Звичайне } \\
\text { десормування }\end{array}$} & \multicolumn{2}{|c|}{$\begin{array}{c}\text { Вібраційне } \\
\text { дерормування }\end{array}$} \\
\cline { 2 - 5 } & $\begin{array}{c}\text { волос } \\
\text { ролика г }\end{array}$ & $\begin{array}{c}\text { Знос } \\
\text { колодки, г }\end{array}$ & $\begin{array}{c}\text { Знос } \\
\text { ролика, г }\end{array}$ & $\begin{array}{c}\text { Знос } \\
\text { колодки, г }\end{array}$ \\
\hline 1 & 0,1105 & 0,1878 & 0,0857 & 0,1457 \\
\hline 2 & 0,1198 & 0,1917 & 0,1001 & 0,1602 \\
\hline 3 & 0,1156 & 0,1503 & 0,0991 & 0,1096 \\
\hline 4 & 0,1174 & 0,1937 & 0,0968 & 0,1597 \\
\hline 5 & 0,1209 & 0,1814 & 0,1042 & 0,1501 \\
\hline $\begin{array}{c}\text { Се- } \\
\text { редній } \\
\text { знос, г }\end{array}$ & 0,1168 & 0,1810 & 0,0971 & 0,1451 \\
\hline
\end{tabular}

3. Ступінь деформації по довжині зразка в 2,33 рази менше при вібраційному деформуванні.

4. Величина зусилля деформування при куті ухилу $\beta=10^{\circ}$ і припуску на обробку $\Pi=2,0$ мм при вібраційній обробці в 2,05...2,7 рази менше, ніж при звичайній.

5. В умовах вібраційного деформування спостерігається більш рівномірна і дрібнозерниста структура зразків.

6. Спрацювання ролика в 1,2 , а колодочки в 1,28 рази менше при вібраційному деформуванні, ніж при звичайному. Це пояснюється більш значним зміцненням поверхні оброблених деталей при вібраційному навантаженні.

\section{Література}

1. Ремонт машин / О.І. Сідашенко, О.А. Науменко та ін; за ред. О.І. Сідашенко, А.Я. Поліського. Київ: Урожай, 1994. 400 с.

2. Бабичев А.П., Бабичев И.А. Основы вибрационной технологии. Ростов н/Д: Издательский центр ДГТУ, 2008. 694 с.

3. Кинасошвили Р.С. Расчет поршневого пальца авиационного двигателя. Москва: Оборонгиз, 1987. 148 с.
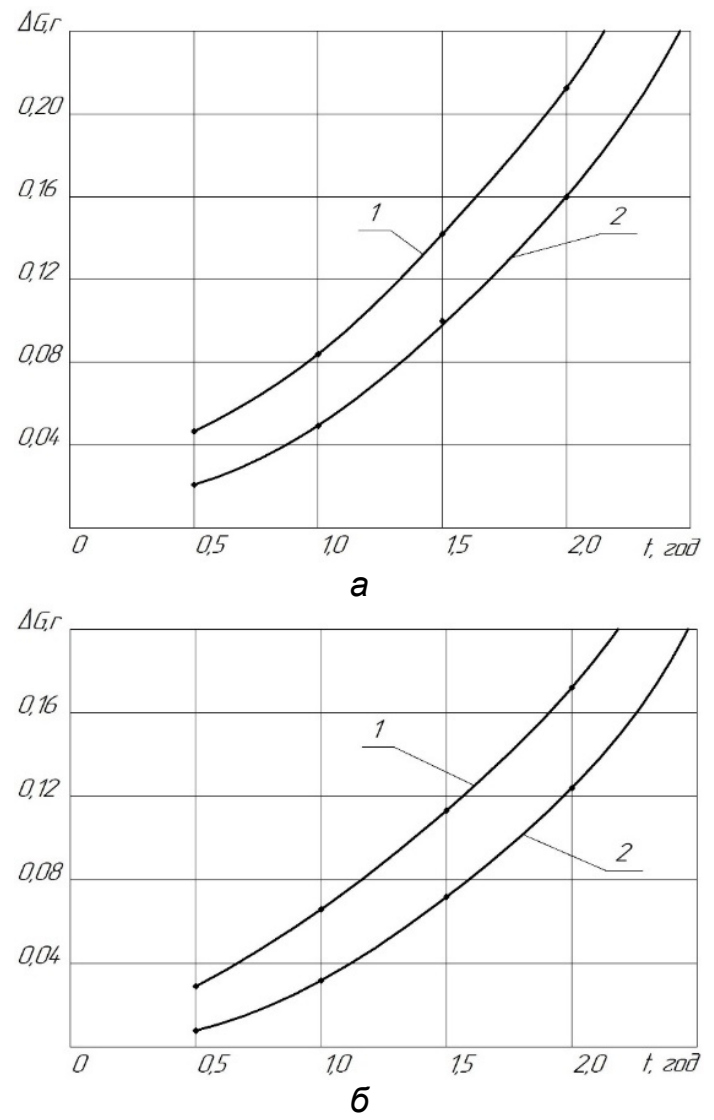

Рис. 2. Криві зносу колодочки (1) і ролика (2) при звичайному (а) і вібраційному (б) деформуванні

\section{References}

1. Sidashenko, O., Naumenko, O. ta in. (1994). Remont mashyn. za red. Sidashenko, O., Poliskoho A. Kyiv: Urozhai, 400.

2. Babichev, A., Babichev, I. (2008). Osnovy vibracionnoj tehnologii. Rostov n/D: Izdatel'skij centr DGTU, 694.

3. Kinasoshvili, R. (1987). Raschet porshnevogo pal'ca aviacionnogo dvigatelja. Moskva: Oborongiz, 148.

\section{Аннотация}

\section{Исследование процесса деформирования материала поршневых пальцев при их восстановлении}

\section{А.А. Дудников, В.В. Дудник, А.И. Беловод, Е.В. Иванкова, Т.Г. Лапенко}

Рассмотрены методы, обеспечивающие повышение долговечности двигателей сельскохозяйственной техники за счет применения эффективных технологий при изготовлении и восстановлении поршневых пальцев.

Предложенный метод восстановления поршневых пальцев автотракторных двигателей с использованием механических вибрационных колебаний обрабатывающего инструмента.

Проведены исследования по выбору основных параметров обрабатывающего инструмента - пуансона, которые способствуют повышению качества восстановления поршневых пальцев двигателей, что обеспечивает их повышенную износостойкость и, следовательно, надежность двигателя.

Установлены виды главных деформаций при обработке материала поршневых пальцев по их длине, наружному и внутреннему диаметрах с указанием их особенностей. 
Определены основные параметры обрабатывающего инструмента - пуансона и их оптимальные значения при обычном и вибрационном деформировании.

Исследовано изменение размеров обрабатываемых образцов по их длине в условиях обычного и вибрационного нагружения.

Найдены значения степени упрочнения материала поршневых пальцев и бронзовых втулок.

Проведены микроструктурные исследования с целью определения влияния метода деформирования на свойства материала поршневых пальцев.

Исследовано влияние метода обработки поршневых пальцев на процесс переноса (налипания) их материала на рабочую поверхность обрабатывающего инструмента - пуансона.

Проведены исследования износостойкости образцов, вырезанных из поршневых пальцев и бронзовых втулок двигателей на машине трения по схеме «ролик-колодочка».

Определена интенсивность износа указанной пары трения по средней величине потери массы ролика и колодочки.

Приведены графические зависимости результатов изнашивания ролика и колодочки при обычном и вибрационном деформировании в зависимости от времени испытания.

Полученные данные при стендовых испытаниях позволяют разработать и внедрить в производство технологический процесс восстановления поршневых пальцев и бронзовых втулок методом вибрационного деформирования.

Ключевые слова: долговечность деталей; обрабатывающий инструмент; вибрационное упрочнения; износостойкость; технологический процесс.

\section{Abstract}

\section{Study of the process of the deformation of material of piston functions at their restraints}

\section{A.A. Dudnikov, V.V. Dudnik, O.I. Bilovod, O.V. Ivankova, T.G. Lapenko}

The methods, which provide increase of durability of engines of agricultural technics due to use of effective technologies at manufacturing and restoration of piston fingers, are considered.

The method of restoration of piston fingers of automotive motor engines with the use of mechanical vibration oscillations of the working tool is proposed.

The researches on the choice of the basic parameters of the processing tool - the punch, which contribute to the improvement of the quality of the restoration of the piston fingers of the engines, provides their increased wear resistance and, consequently, the reliability of the engine.

The types of main deformations in the processing of material of fingers on their length, external and internal diameters with indication of their features are established.

The changes in the sizes of the processed samples by their length under conditions of normal and vibration load are researched.

The values of the degree of strengthening of material of piston fingers and bronze bushings are found.

Microstructural studies have been conducted to determine the effect of the deformation method on the properties of the piston fingers metal.

The influence of the method of processing the piston fingers on the process of transfer (sticking) of their material to the working surface of the working tool - punch is investigated.

Studies of wear resistance of samples, cut from piston fingers and bronze bushings of engines on a friction machine according to the scheme "roles - a shoe".

The intensity of wear of the specified friction pair is determined by the average value of the weight loss of the roller and the shaft.

The graphic dependences of the results of the wear and tear of the roller and the block in normal and vibration deformation, depending on the time of the tests, are given.

The results of bench tests allow to develop and introduce into production the technological process of restoration of piston fingers and bronze bushings by the method of vibration deformation.

Keywords: durability of details; processing tool; vibration strengthening; durability; technological process.

\section{Бібліографрічне посилання/ Bibliography citation: Harvard}

Dudnikov, A., Dudnik, V., Bilovod, O., Ivankova, O., and Lapenko, T. (2019). Study of the process of the deformation of material of piston functions at their restraints. Engineering of nature management, 3(13), pp. 30 - 34.

Подано до редакції / Received: 02.05.2019 